\section{STEM Faculty as Learners in Pedagogical Reform and the Role of Research Articles as Professional Development Opportunities}

\author{
Amy B. Mulnix*
}

Franklin and Marshall College, Lancaster, PA 17604

\begin{abstract}
Discipline-based education research (DBER) publications are opportunities for professional development around science, technology, engineering, and mathematics (STEM) education reform. Learning theory tells us these publications could be more impactful if authors, reviewers, and editors pay greater attention to linking principles and practice. This approach, which considers faculty as learners and STEM education reform as content, has the potential to better support faculty members because it promotes a deeper understanding of the reasons why a pedagogical change is effective. This depth of understanding is necessary for faculty members to successfully transfer new knowledge to their own contexts. A challenge ahead for the emergent learning sciences is to better integrate findings from across sister disciplines; DBER reports can take a step in that direction while improving their usefulness for instructors.
\end{abstract}

\section{CONTRIBUTIONS OF DISCIPLINE-BASED EDUCATION RESEARCH PUBLICATIONS TO STEM EDUCATION REFORM}

The emerging field of the learning sciences is integrating and extending perspectives from cognitive, social, and cultural psychology; cognitive neuroscience; education; discipline-based education research (DBER); and many other fields (e.g., Ambrose et al., 2010; Slavich and Zimbardo, 2012). These insights promise to deepen learning for all students and close achievement gaps for groups underrepresented in the sciences (Mulnix et al., 2016). DBER has made and continues to make essential contributions to improving science, technology, engineering, and mathematics (STEM) undergraduate education (National Research Council [NRC], 2012a; Kober, 2015). Especially in recent years, the appearance of DBER in premier research journals such as Science (e.g., Haak et al., 2011), Proceedings of the National Academy of Sciences (e.g., Freeman et al., 2014), and Cell (e.g., Stockwell et al., 2015) has made these exciting advances in learning sciences apparent to an even broader STEM audience.

But there is potential for DBER publications to contribute more to STEM education reform than just reporting research findings (Brownell and Tanner, 2012). For instance, as points of contact with faculty members who are not regular readers of education literature, articles in high-impact journals can raise awareness and understanding of evidence-based pedagogies (EBP; Bouwma-Gearhart, 2012; Brownell and Tanner, 2012; Lund and Stains, 2015). Additionally, the relatively high citation rate and visibility of such articles likely makes them models for subsequent publications.

And while some recent research suggests that lack of knowledge is a diminishing barrier to reform efforts (Borrego et al., 2010; Henderson et al., 2012; Lund and Stains, 2015), models (e.g., Table 1) for how change occurs in STEM pedagogy suggest publications have impact at points beyond introduction to ideas (Henderson et al., 2012; Lund and Stains, 2015). For example, Bouwma-Gearhart (2012) suggests that the education literature provides resources for faculty members both to explore EBP in
Deborah Allen, Monitoring Editor

Submitted December 8, 2015; Revised April 13, 2016; Accepted April 15, 2016

CBE Life Sci Educ December 1, 2016 15:es8

DOI:10.1187/cbe.15-12-0251

*Address correspondence to: Amy B. Mulnix (amy mulnix(afandm.edu).

(c) 2016 A. B. Mulnix. CBE-Life Sciences Education (c) 2016 The American Society for Cell Biology. This article is distributed by The American Society for Cell Biology under license from the author(s). It is available to the public under an Attribution-Noncommercial-Share Alike 3.0 Unported Creative Commons License (http://creativecommons.org/licenses/ by-nc-sa/3.0).

"ASCB $®$ " and "The American Society for Cell Biology ${ }^{\circledR}$ " are registered trademarks of The American Society for Cell Biology. 
TABLE 1. Faculty use of literature during reform of teaching practices

\begin{tabular}{lccc}
\hline \multicolumn{4}{c}{ Innovation-decision model of change } \\
\hline $\begin{array}{l}\text { Knowledge vs. no } \\
\text { knowledge }\end{array}$ & $\begin{array}{c}\text { Tried vs. not } \\
\text { tried }\end{array}$ & $\begin{array}{c}\text { Current user } \\
\text { vs. former } \\
\text { user }\end{array}$ & $\begin{array}{c}\text { High user vs. } \\
\text { low user }\end{array}$ \\
Y & Y/Y & Y/N & Y/Y \\
\hline
\end{tabular}

Henderson et al. (2012) identified variables correlated with use of EBP. Reading the literature regularly was the only significant variable identified as important at more than two stages in the innovation-decision model. Y/Y indicates that the regular reading of the literature was significantly correlated as an individual variable and when the other significant variables were controlled for. $\mathrm{Y} / \mathrm{N}$ indicates that regular reading of the literature was positively correlated when examined individually but not when the other variables were controlled for.

low-risk, private environments and to troubleshoot new approaches in real time.

As shown in Table 1 (Henderson et al. 2012), some research bears this out: regular reading of STEM education journals does positively correlate with persistence of physics faculty at multiple stages in the transition to EBP. These stages include knowledge acquisition, motivation to try pedagogical innovations, and being a high-frequency user. This makes intuitive sense. Faculty members turn to education literature to initially learn about EBP and become enthused by the reported positive results. After gaining experience, they further explore the literature to add more practices to their alternative pedagogy tool kits (e.g., Major and Palmer, 2006).

Faculty members also encounter educational research literature as part of professional development programs. For example, journal clubs ${ }^{1}$ (DaRosa and Simpson, 2012; Pusateri, 2014) and learning communities (McDaniel 1987; Cox, 2001, 2004; Lenning et al., 2013; Stewart, 2014) are relatively common opportunities offered by teaching and learning centers. Although practices vary, both of these activities use publications to improve pedagogical knowledge and practice. Faculty members gather to have deep and critical discussions about the findings, limitations, and implications of research. In some graduate and postdoctoral programs (e.g., www.cirtl.net/CIRTLReads-2015 -2016; http://otl.wayne.edu/programs/stem.php) learning science research literature is used to strengthen pedagogical knowledge and, hopefully, teaching skills. Journal clubs, familiar to many STEM faculty for their use in discussion of disciplinary research papers, are typically less demanding and structured than formal learning communities (Cox, 2001, 2004; Vescio et al., 2008), which include intentional application of scholarly work in the classroom and an expectation of shared practice, such as observing one another's teaching. Additionally, professional developers often send research articles to interested faculty members, suggest readings for learning communities, provide bibliographies to workshop participants, or present a seminar based on particularly noteworthy research findings.

But change is a context-dependent process (Kezar, 2009); individuals, departments, and institutions differ in how they approach and accomplish STEM education reform. Lund and

\footnotetext{
${ }^{1}$ An Internet search identified journal clubs that examine education literature to be offerings within teaching and learning centers at Yale University, the University of Minnesota, and the Georgia Institute of Technology, among many others.
}

Stains (2015, p. 23) report that DBER articles are "largely underutilized" for learning about and implementing EBP by physics, chemistry, and biology faculty within a single institution. Henderson et al. (2012) also found the correlation of literature use and pedagogical change by STEM faculty to be complex; although several stages of change are correlated with use of EBP, continued use after trying new approaches is not when other variables (e.g., gender, class size) are controlled for. From this and other data, Henderson et al. (2012, p. 11) suggest that research articles and other dissemination methods such as workshops "do not support maintained use of these innovations."

This complexity should not be surprising. Not only is change context dependent, it is messy even under the best conditions. It requires iterative practice and is rarely, if ever, accomplished through reading alone. And, while the primary goal of a research article is to report findings rather than support STEM faculty change, pedagogical reform is progressing slowly (American Association of Colleges and Universities [AACU], 2015; President's Council of Advisors on Science and Technology [PCAST], 2012)—at what some might describe as a glacial pace. When DBER articles are published in high-profile disciplinary research journals there is an opportunity to recruit more faculty members to reform. Can their impact on the change process be enhanced? Learning theory suggests the answer to this question is yes.

One model for pedagogical reform-how it occurs, what promotes it, how barriers can be overcome-is to consider the process as a learning phenomenon (Mulnix, 2013, 2016). How people learn is the content. Faculty members and administrators are the learners. Moving from novice to expert in understanding and applying learning theory is the learning goal. Reformed classroom practice is the outcome at the individual level; reformed processes and practices are the outcomes at the institutional level.

\section{FACULTY AS LEARNERS IN THE REFORM PROCESS}

Those involved in faculty development have long viewed their professional roles as facilitating learning, even applying the term "learner" to faculty members (e.g., Borko, 2004; McDaniel, 1987). Shulman (1986, p. 4) made the idea of faculty as learners clear for K-12 teachers in his seminal article, which examined "knowledge growth in teaching." Schulman (1986) argued that teachers learn not ony about pedagogy (e.g., how to accomplish active learning or group work) but also learn pedagogical content knowledge (PCK)-the knowledge a teacher learns about teaching in his or her particular discipline (e.g., What are the likely misconceptions? What are useful metaphors? What approaches are successful?). Others (e.g., McDaniel, 1987; Gess-Newsome et al., 2003) have applied Shulman's ideas to higher education. Major and Palmer (2006) use the lens of PCK to examine the process of university faculty adopting problem-based learning at the institutional level; their study indicates that professional development activities not only support learning PCK but can bring about transformative change.

Accordingly, professional developers embed learning theory in their programs (e.g., Sunal et al., 2001; Stewart, 2014). STEM education researchers also advise use of what is known about learning to assist faculty members in reform. For example, Hilborn (2012) advocated for STEM education 
workshops to incorporate the content of Ambrose et al. (2010) to better support learning by faculty members. In their report on change in entrepreneurship education in engineering programs, Giersch and McMartin (2014) similarly argue for faculty development interventions to be informed by learning theory and principles of instructional design. Kezar (2009) argues that, for STEM education reform to be successful, faculty must engage in learning that allows sense to be made of the changes under way.

While those involved in professional development view faculty members as learners, faculty members do not always perceive themselves in this role. Indeed, I have argued elsewhere (Mulnix, 2016) that helping faculty members see the parallels between their own learning about learning and their students learning content is important to transformational pedagogical change. Table 2 explores this premise of pedagogical reform as a learning process for faculty by interpreting observations of STEM education reform from the point of view of faculty members as learners. For instance, the principle that learning is enhanced by practice with feedback applies to students who benefit from low-stakes quizzes in ways similar to faculty who benefit from the kind of formative peer evaluation that occurs in learning communities.

Table 3 further explores the idea of faculty as learners by highlighting parallels between faculty members and students as naïve learners. For instance, the fact that faculty members rely on pedagogies familiar to them from their own prior experiences in education mirrors the fact that students use study strategies that were successful for them in high school. Both populations resist changing their behaviors, even in the face of evidence that those practices do not optimize learning. Another example: faculty members, like students, can have incomplete understandings that are problematic for further learning.
Richardson (1990), Tobias (1992), Michael (2007), Blackie et al. (2010), Nelson (2010), and Boyd (2014) are among those who explore naïve conceptions held by faculty about learning and/or reform.

When faculty members are viewed as learners, the impact of research articles on pedagogical reform can be enhanced. One way to accomplish this is to explicitly consider research reports as educational tools and apply what is known about learning to their content and presentation. Learning science itself tells us that grounding new information in theory is key to moving learners along the continuum from novice to expert. Incoming knowledge that remains disconnected, conceptually unorganized, and isolated from underlying principles is not deeply understood nor easily retrieved (NRC, 2000, 2012a). This knowledge remains inert; it is difficult to use in new contexts. This means that, for reports of research findings to have the greatest impact on reform, the learning principles that might be at work need to be foregrounded and the details of the experiments and their results need to be better tied to theory.

Principles are schemes that capture relationships; they elucidate the why and how. They have explanatory power across multiple contexts: student age, institution, discipline, instructor, class size, and so on. They allow sense to be made of disparate observations such as the facts that reading questions, quizzing before class, identifying muddy points, and reviewing class notes all enhance learning. That structure determines function is one example of a broad principle in cell biology; that signal transduction is typically initiated by a small molecule triggering protein conformational change is another. While obvious in definition and example, the principles around which an expert organizes knowledge are typically unrecognized at a conscious level (Ambrose et al., 2010). The fluency and automaticity of

TABLE 2. Comparison of student and faculty experiences as learners

\section{Experience of students learning \\ Learning principle disciplinary content}

Learning is dependent on prior experiences and knowledge. Learning is a social process.

Learning environments have embedded cultural messages.

Learning is maximized by practice and abundant, timely, and relevant feedback.

Some students arrive at college with low content background and skill development.

Students benefit from practices such as thinkpair-share, peer instruction, and group work that require students to interact with their peers (Kober, 2015).

There is a "hidden curriculum" in traditional STEM classrooms that rewards a narrow set of behaviors, attributes, and prior experiences, namely those associated with lecture. Making these invisible expectations explicit can aid students from different cultural backgrounds (Margolis, 2001).

Performance is improved when students have opportunities to practice recalling and using knowledge in low-stakes evaluations with time to improve performance based on feedback (NRC, 2012b; Carpenter, 2014).

Significant time on task is required for deep learning.
Students must spend time truly engaged in the material to make learning effective.
Experience of faculty members learning about learning

Faculty members typically receive little/no formal training before their first teaching jobs.

Faculty members identify lack of collegial and departmental support as a barrier to change (Brownell and Tanner, 2012).

Teachers identify discussion as important to learning about learning (King, 2004; Vescio et al., 2008).

That the professional identities of faculty members are often more as scientists and less as teachers is identified as a barrier change (Brownell and Tanner, 2012).

The particular teaching climate at an institution impacts the success of professional development interventions (Condon et al., 2015).

Faculty members benefit from participation in learning communities that involve shared practice (e.g., Gruppen et al., 2003).

Gormally et al., 2014 argue that "providing faculty with formative teaching feedback may be the single most underappreciated factor in enhancing science education reform efforts" (p. 188).

Faculty members identify time constraints as a barrier to revamping pedagogies (Zakrajsek, 2013). 
TABLE 3. Examples of learner statements that illustrate parallels between faculty and students as learners

\begin{tabular}{ccc}
\hline & Examples of learner statements & \\
\hline Faculty & Student \\
\hline
\end{tabular}

Learners have a knowledge and experience history that is unique. This history can aid learning, or it can hamper it.

"I don't understand why today's students need more than a good lecture and a textbook to learn."
"I don't understand why I got a 'C' on the test, I studied my flashcards and highlighted the reading."

Learners have naïve conceptions that limit learning and prevent deep understanding.

"Group work results in the weaker students parasitizing the stronger ones."

"Students should readily recall what has been covered in prerequisite courses."

"I teach large classes in auditorium-style classes; active learning just isn't possible."

Learners have difficulty transferring information learned in one context to another.

"I see why providing connections to the lives of students is important, but there just aren't many examples of how molecular biology relates to real life."

Learners are more successful when the value of what is being learned is made obvious.

"I don't see a need to change my teaching; my teaching evaluations are "I didn't really do the reading; the teacher always lectures on what's quite good." in the book."

Statements in the table are not direct quotes but are aggregates that reflect views expressed in workshops with STEM faculty members and teaching-learning experiences with students.

understanding for an expert are so great that the underlying structure and process is typically taken for granted unless explicitly explored (e.g., Feldon et al., 2010).

\section{PRACTICAL APPLICATIONS OF LEARNING PRINCIPLES}

In the case of learning, principles offer explanations for why a particular pedagogical choice is effective. What is it about active learning or increased course structure or problem solving during class that might be responsible for an increase in learning? These principles typically trace back to patterns of brain function and mechanisms of information processing. Below is a selection of learning principles sufficiently robust to have been identified in multiple literature reviews and textbooks. These have been derived from extensive empirical evidence across multiple disciplines. Two sets of examples are provided to illustrate practical use of the principle. The first is for the context of student learning. The second set considers how the principles can be used for faculty development, specifically around discussion of a DBER article.

1. Learners have a knowledge and experience history that is unique. This history can aid learning, or it can hamper it. Because prior knowledge is literally written into the physical connections among neurons (called encoding), unless new information becomes wired into existing networks it will be lost. Thus, effective instruction must take into account the prior knowledge of the learner and appropriately connect to it (NRC, 2000; Wood, 2009; Ambrose et al., 2010).

For students: An upper-level molecular genetics course might explore evolution of primate color vision (Jacobs and Nathans, 2009) as a model for consolidating knowledge of loci, alleles, gene duplication, mutation, and Mendelian inheritance patterns previously covered in an introductory genetics course.
For faculty: Discussion of a DBER article could begin with faculty members identifying ways in which their classrooms already accomplish a suggested intervention such as active learning.

2. Deep factual knowledge is insufficient for expertise. Expert knowledge is organized into a highly interconnected conceptual framework that facilitates retrieval and application. Novices not only have less knowledge, they also lack a robust framework for organizing information. Without organization and connectedness, knowledge can be present but not recognized as having relevance when needed (NRC, 2000; Moog et al., 2006; Wood, 2009; Ambrose et al., 2010).

For students: A project that uses information at the National Center for Biotechnology Information website to investigate a genetic disease-tracing disruption of the affected gene from the mutation through the impact on transcription and/ or translation to explain the resulting physiological consequences (Mulnix and Penhale, 1997)—can provide an opportunity for students to clarify and conceptually organize components of the central dogma of molecular biology.

For faculty: Having identified ways that students engage in active learning in their classrooms, faculty members could explain how those activities embody learning principles such as those listed here and how those activities could be modified to enhance them.

3. Learner motivation matters (Ambrose et al., 2010). While learners themselves play a significant role in their motivation, so do teachers. Instructors and environments that prime student motivation aid learning and promote the ability to transfer knowledge to novel contexts (NRC, 2012b). One means for priming student motivation is to use real-life examples (Doyle, 2011). 
For students: Someone teaching molecular genetics might ask students to draft and enact a simulated genetic counseling scenario, create posters that market new RNA drugs in a mock conference for physicians, or prepare evidence about the role of epigenetics to be given in a mock legislative hearing on funding for preschools.

For faculty: Faculty members could be asked to critique an assignment description or syllabus and then modify it to better incorporate the ideas from the research article being discussed.

4. Learning is enhanced when novices have opportunities to explain new information to themselves and to others (Wood, 2009; Ambrose et al., 2010; NRC, 2012b). Elaboration, whether in written, diagrammatic, or oral form, is a powerful learning tool.

For students: An assignment that asks student pairs to read a research article on the structure of a protein and then present the findings of that paper in poster format is one means of engaging students in the process of explanation not only to themselves but also to their peers (Mulnix, 2003).

For faculty: A discussion of a DBER article could include pairs of faculty identifying questions that were raised for them as they read the article. These could then be shared in the group.

5. Practice with new information is key to retention of learning, and it enhances depth of learning. Practice that is distributed over time has been shown to be more effective then massed practice such as cramming (Carpenter, 2014; Dunlosky et al., 2013).

For students: Quizzes, rewriting notes, coverage of topics in both lecture and laboratory formats, and projects such as those described in the items above provide opportunities for practice with feedback (see point 6).

For faculty: Pairs in the discussion group could be asked to follow up with each other three times over a semester about how their teaching practices have changed as a result of discussing the research article.

6. Frequent, prompt, and relevant feedback timed to allow for improvement in performance is key to deep learning (Wood, 2009; Ambrose et al., 2010; NRC, 2012b). This formative (versus summative) feedback does not need to involve grading and can come from peers, answer keys, supplemental instructors, and faculty talking aloud through an answer after students have attempted to answer it.

For students: Giving students opportunities to evaluate a data set as part of content presentation during class time can serve as practice with feedback before encountering similar questions on exams (see the Supplemental Material).

For faculty: Faculty could make peer visits to one another's classrooms to observe new techniques being used and then discuss areas of strength and those needing adjustment. Alternatively, faculty members might videotape a class and then do a self-evaluation using materials from Harvard's Best Foot Forward program (http://cepr.harvard.edu/video -observation-toolkit) as guides. This tool kit is designed for use in $\mathrm{K}-12$, but features are applicable to higher education as well.

7. Reflection and metacognition assist learners in defining goals, selecting learning strategies, and monitoring progress toward those goals. Awareness of one's learning as a process in progress provides opportunity for greater insight into and control of that process. (NRC, 2000, 2012b; Wood, 2009; Ambrose et al., 2010).

For students: Exam wrappers (Lovett, 2013) are one example of strategies to promote reflection and metacognition.

For faculty: Discussion of a DBER article might include exploring ways in which individual faculty might be resistant to incorporating a change (e.g., giving up control during an activity, covering less content). Additionally, quiz or exam questions that measure student learning outcomes using the alternative technique could be used to assess the change.

While these principles can be can be articulated in isolation, they are mutually reinforcing. Connecting new to existing knowledge can be motivating. Elaboration is a form of practice. Feedback can support metacognition. Practice can assist in organizing information according to concepts. Indeed, in discussion of a DBER article by faculty, any one of the suggested approaches is addressing multiple learning principles.

\section{DBER PUBLICATIONS AND LEARNING PRINCIPLES INTEGRATED}

Table 4 further illustrates how these principles might map onto the practices empirically demonstrated to enhance learning. For instance, depending on the specifics of the activity, in-class problem solving could 1) connect incoming information to students' prior knowledge, 2) facilitate organization of knowledge into a conceptual framework, 3) motivate learners via social interactions, 4) provide opportunities for elaboration by self and with peers, 5) offer feedback from peers and/or faculty members, and/or 6) make the learner aware of learning strategies used by others. Discussion of these or other (see Ambrose et al., 2010; Mayer and Alexander, 2011; Dunlosky et al., 2013; Benassi et al., 2014; Brown et al., 2014) principles in the introduction, methods, discussion, and implications sections of research articles can provide a conceptual framework for readers and assist in their construction of an expert organization of knowledge.

When authors, for instance, indicate that in-class activities were designed to promote peer-peer interactions in ways that elicited feedback for students about their understandings, the article provides the conceptual structure readers need to make informed choices in their own classes. Use of clickers and thinkpair-share and small-group work to solve problems become rich interventions rather than activities to include for the sake of "active learning." Explaining that reading questions devised to help students develop more interconnected knowledge structures and to connect new to existing knowledge would guide faculty members as they create and modify supports for their own students. Readers of research articles begin to see that it is not the particular activity (e.g., clicker questions or think-pair-share) that is important but rather how that activity promotes learning. Understanding the mechanical details of flipped classrooms, 
TABLE 4. How learning principles can map onto examples of pedagogical practices

\begin{tabular}{|c|c|}
\hline Evidence-based practice & Learning principles that may be at work \\
\hline $\begin{array}{l}\text { Preparation before class: } \\
\text { - providing students with reading questions, } \\
\text { - quizzing before arrival in class } \\
\text { - instruction via video } \\
\text { (e.g., Freeman et al., 2011; Haak et al., 2011; Offerdahlt } \\
\quad \text { and Montplaisir, 2013; Gross et al., 2015) }\end{array}$ & $\begin{array}{l}\text { - Creating expert organization of knowledge } \\
\text { - Providing cues about the larger concepts and how to hang details on that } \\
\text { framework } \\
\text { - Engaging prior knowledge, including misunderstandings } \\
\text { - Highlighting common misunderstandings of information } \\
\text { - Scaffolding may help students grasp ideas in a logical order or in smaller steps }\end{array}$ \\
\hline
\end{tabular}

active learning, and increased course structure is necessary but insufficient to allow evaluation, creation, and troubleshooting in one's own classroom context. It takes an understanding of the critical attributes of these pedagogical tools to make them effective in other contexts. Richardson (1990, p. 16) argued more than 20 years ago for education researchers to make their theoretical framework obvious to practitioners so that teachers can "relate the activity's theoretical framework to their own beliefs and understandings." In this way, teachers have opportunities to take control of their choices rather than have a given practice imposed by external forces. "Without such empowerment, teachers may become victims of their personal biographies, systemic political demands, and ecological conditions, rather than making use of them in developing and sustaining worthwhile and significant change" (Richardson, 1990, p. 16).

But don't university faculty have the wisdom and experience to intuit this conceptual foundation? In fact, there are suggestions in the literature that STEM faculty members do not make these conceptual leaps. For instance, when Andrews et al. (2011) studied a broadly representative set of introductory-level biology instructors self-reporting use of active-learning strategies, little evidence of gains in student learning were documented. This suggests a surface rather than a deep understanding of research findings. Furthermore, instructors' modifications of published practices often diminish the effectiveness of those practices (Dancy and Henderson, 2010). Faculty using EBP in the classroom have also been shown: 1) to rely on personal over empirical evidence (Cooper, 2014; Andrews and Lemons, 2015), 2) to have personal beliefs inconsistent with recommended practice (Borrego et al., 2013), and 3) to misrepresent the degree to which they use reformed practices (EbertMay et al., 2011). The finding that the largest loss of physicists in reform efforts was at the continuation stage (Table 1; Henderson et al., 2012) also suggests that faculty may lack suffi- cient depth of understanding of reform practices to personalize their use.

In a model for reform that views faculty as learners, the difficulties encountered when changing practices built over a career are not surprising. Difficulty troubleshooting when using a practice in a new context, returning to prior approaches that are comfortable, inaccurate estimates of progress in reform, and questions about the value of the work required are all hurdles encountered by novices. Even as expert learners in their discipline, most faculty members are novices to the learning sciences. They need the theory behind new practices made evident. The robust literature in the area of job training (e.g., McGehee and Thayer, 1961; Baldwin and Ford, 1988; Grossman and Salas, 2011) also indicates that applying learning principles when designing professional learning/job training is key to subsequent use of knowledge by employees. In essence, STEM education reform is a problem of knowledge transfer; faculty members must use-that is, apply, evaluate, synthesize, and create-their knowledge in novel contexts. Such transfer has been empirically shown to be promoted by a deep understanding of the fundamental principles at work (NRC, 2000, 2012b).

While some DBER articles are thin on theory, there are many examples that effectively communicate the links among practice and learning science principles. Offerdahlt and Montplaisir (2013) integrate a robust treatment of formative assessment into their introduction about how student-generated reading questions provide a window into student understanding. In doing so, they not only address feedback but also knowledge construction, knowledge organization, and metacognition. Similarly, Gross et al. (2015) use their introductory remarks to contextualize the roles of student motivation and distributed practice as underlying principles for improved student performance. Eddy and Hogan (2014) consider increased practice 
with material (Freeman et al., 2011) as a factor through which increased course structure achieves enhanced learning. They explore time on task, class community, and perceived value of the course as additional factors contributing to effectiveness. Linton et al. (2014) explicate why writing may be effective as a component of active learning, considering knowledge construction and organization, feedback, and metacognition as possible contributors in their introductory comments. Mack and Towns (2016) also provide a strong theoretical foundation for their examination of faculty beliefs about teaching undergraduate physical chemistry.

My main thesis is that, when theoretical foundations are overlooked in DBER publications, the impact of the publication is diminished because readers do not encounter the information that can help them bring new practices to their own classrooms. But also worrisome is the fact that absence of theory perpetuates misinformation about the learning sciences. It allows the erroneous belief (e.g., Zhang et al., 2010; Weimer, 2013) that evidence supporting the effectiveness of EBP is relatively new and remains insubstantial to remain unchallenged. Colleagues and I (Mulnix et al., 2016) have experienced such misunderstandings in our work with STEM faculty, and hesitancy about quality and quantity of evidence is often implicit in the sections of papers and reports that continue to address sufficiency of evidence of effectiveness of alternative practices (e.g., Fairweather, 2008; Appendix F in PCAST, 2012; Mack and Towns, 2016). While evidence of effectiveness of reformed practices has not resulted in widespread adoption, removing doubt in the minds of STEM faculty could reduce a barrier to reform.

\section{DBER, A MATURING FIELD}

Others (Ansari and Coch, 2006; Fairweather, 2008; Hilborn, 2012; D’Avanzo 2013; Coppola and Krajcik 2014; Talanquer, 2014) have also noted the need to better integrate DBER with sister disciplines in the learning sciences. Such integration of knowledge seems part and parcel of the emergence of learning science as a discipline. As the field matures, connections among findings and patterns that are consistent across disciplines become obvious. The conceptual understanding of the field deepens.

Indeed, DBER experts themselves can gain insights from analyzing their own and the STEM community's reform processes. These reflective and metacognitive insights can then be used to anticipate the intellectual gaps and challenges that peers at early stages in reform are likely to encounter. This is similar to faculty members using disciplinary pedagogical content knowledge to anticipate the misunderstandings that undergraduates are likely to experience. Linking theory and practice is an area DBER is growing into, with peers pointing out the need as the field advances. We can learn from this experience: faculty members are likely to also need support in making these intellectual connections.

So, how can research publications better contextualize DBER within learning science theory and empirical findings from sister disciplines? How can they better support faculty in the transition to EBP? Attention of authors, reviewers, and editors to the following aspects of DBER publications are among the actions that could be taken:
1. Explicitly integrate learning principles into subsections of a paper, particularly the introduction and conclusion. The learning principles that could be at work when increased learning is observed need to be discussed not only to enhance the quality of the paper but to also better educate readers.

2. Provide citations to the relevant literature in sister disciplines, not just DBER. The robust evidence that EBP enhances and deepens learning is summarized in several reviews (NRC, 2000, 2012a,b) authored by committees of national experts tasked with integrating and evaluating findings across the branches of the learning sciences. Available as free downloadable PDFs from the National Academies Press, these contain extensive bibliographies. Additional summaries and syntheses with translations to classroom applications are also available (Ambrose et al., 2010; Dunlosky et al., 2013; Kober, 2015).

3. Report sufficient details that practices can be replicated elsewhere. With the advent of online supplementary materials, examples of tools such as videos, in-class problems, and multiple-choice exams can be shared.

4. Supplementary materials should additionally be annotated so that novice faculty can see the learning principles at work and have guidelines for implementing them in their own contexts (e.g., see the Supplemental Material for this article).

Including these items would enrich the context for the research, provide a more accurate description of the state of the field, and provide critical resources for novices. The urgency with which the STEM community needs to accomplish undergraduate educational reform (PCAST, 2012; AACU, 2015) heightens the need for top-tier journals to model pedagogical excellence.

\section{CONCLUSION}

In summary, educational theory (Ambrose et al., 2010; Sousa, 2010; Mayer and Alexander, 2011; NRC, 2000, 2012b; Fink, 2013) tells us that a deep understanding of content is necessary for successful transfer of knowledge to novel situations. Such depth is not only about acquiring information but also about organizing and connecting it so relevant knowledge is recognized when needed. As learners, faculty members in the process of reform must not only build their factual knowledge but must organize that knowledge and experience to allow deep and transformative learning. An understanding of the learning principles that are the foundation for alternative teaching and learning strategies can help faculty members develop the ability to transfer knowledge to their own circumstances. This line of reasoning suggests that DBER needs to better identify and explicate learning principles that could account individually or in combination for improvement on measures of learning. This is important for assisting novice STEM faculty in their transition to reformed pedagogical practices.

Because reform efforts are progressing so slowly, publications reporting DEBR results, especially those in high-impact journals, have a corollary function of professional development. This function adds an additional responsibility for authors, reviewers, and editors: to explicitly consider how effective a paper is as a point of learning for faculty. 
DBER experts are pioneers in an emerging field. By explicitly tying practice to learning principles emerging from sister disciplines, they can greatly help novices in the learning process. DBER experts have blazed a trail. Creating maps, adding trail markers, providing signposts, constructing bridges, building stairs, and adding guardrails will help more people travel the route successfully.

\section{ACKNOWLEDGMENTS}

A.B.M. is supported in part by a grant from the Andrew W. Mellon Foundation to Franklin and Marshall College.

\section{REFERENCES}

Ambrose SA, Bridges MW, DiPietro M, Lovett MC, Norman MK (2010). How Learning Works: 7 Research-Based Principles for Smart Teaching, Sacramento, CA: Jossey-Bass.

American Association of Colleges and Universities (2015). Step Up and Lead for Equity: What Higher Education Can Do To Reverse Our Deepening Divides, Washington, DC. www.aacu.org/sites/default/files/ StepUpLeadEquity.pdf (accessed 20 October 2016).

Andrews TC, Lemons PP (2015). Its personal: biology instructors prioritize personal evidence over empirical evidence in teaching decisions. CBE Life Sci Educ 14, ar7.

Andrews TM, Leonard MJ, Colgrove CA, Kalinowski ST (2011). Active learning not associated with student learning in a random sample of college biology courses. CBE Life Sci Educ 10, 394-405.

Ansari D, Coch D (2006). Bridge over troubled waters: education and cognitive neuroscience. Trends in Cogn Sci 10, 146-151.

Baldwin TT, Ford JK (1988). Transfer of training: a review of directions for future research. Person Psychol 41, 63-105.

Benassi VA, Overson CE, Hakala CM (eds.) (2014). Applying Science of Learning in Education: Infusing Psychological Science into the Curriculum, Washington, DC: Society for the Teaching of Psychology.

Blackie MA, Case JM, Jawitz J (2010). Student-centeredness: the link between transforming students and transforming ourselves. Teach High Educ 15, 637-646.

Borko H ( (2004). Professional development and teacher learning: mapping the terrain. Educ Res 33(8), 3-15.

Borrego M, Froyd JE, Hall TS (2010). Diffusion of engineering education innovations: a survey of awareness and adoption rates in US engineering departments. J Eng Educ 99, 185-207.

Borrego M, Froyd JE, Henderson C, Cutler S, Prince M (2013). Influence of engineering instructors' teaching and learning beliefs on pedagogies in engineering science courses. Int J Eng Educ 29, 1456-1471.

Bouwma-Gearhart J (2012). Science faculty improving teaching practice: identifying needs and finding meaningful professional development. Int J Teach Learn High Educ 24, 180-188.

Boyd D (2014). The growth mindset approach: a threshold concept in course redesign. J Cent Teach Learn 6, 29-44.

Brown PC, Roediger H, McDaniel MA (2014). Make It Stick, Cambridge, MA: Harvard University Press.

Brownell SE, Tanner KD (2012). Barriers to faculty pedagogical change: lack of training, time, incentives, and ... tensions with professional identity? CBE Life Sci Educ 11, 339-346.

Carpenter S (2014). Spacing and interleaving of study and practice. In: Applying Science of Learning in Education: Infusing Psychological Science into the Curriculum, ed. VA Benassi, CE Overson, and CM Hakala, Washington, DC: Society for the Teaching of Psychology.

Condon W, Iverson ER, Manduca CA, Rutz C, Willett G (2015). Faculty Development and Student Learning, Bloomington: Indiana University Press.

Cooper MM (2014). Evidence-based reform of teaching and learning. Anal Bioanal Chem 406, 1-4.

Coppola BP, Krajcik JS (2014). Discipline-centered post-secondary science education research: distinctive targets, challenges and opportunities. J Res Sci Teach 51, 679-693.
Cox MD (2001). Faculty learning communities: change agents for transforming institutions into learning organizations. To Improve the Academy 19, 69-93.

Cox MD (2004). Introduction to faculty learning communities. New Dir Teach Learn 97, 5-23.

Crouch $\mathrm{CH}$, Mazur E (2001). Peer instruction: ten years of experience and results. Am J Phys 69, 970-977.

Dancy MH, Henderson C (2010). Pedagogical practices and instructional change of physics faculty. Am J Phys 78, 1056-1063.

DaRosa DA, Simpson D (2012). Faculty development, In: ACE Guidebook for Clerkship Directors, 4th ed., North Syracuse, NY: Gegensatz, 531-566.

D'Avanzo C (2013). Post Vision and Change: do we know how to change? CBE Life Sci Educ 12, 373-382.

Doyle T (2011). Learner-Centered Teaching: Putting the Research on Learning into Practice, Sterling, VA: Stylus.

Dunlosky J, Rawson KA, Marsh EJ, Nathan MJ, Willingham DT (2013). Improving students' learning with effective learning techniques: promising directions from cognitive and educational psychology. Psychol Sci Public Interest 14, 4-58.

Ebert-May D, Derting TL, Hodding J, Momsen L, Long TM, Jardeleza SE (2011). What we say is not what we do: effective evaluation of faculty development programs. BioScience 61, 550-558.

Eddy SL, Hogan KA (2014). Getting under the hood: how and for whom does increasing course structure work? CBE Life Sci Educ 13, 453-468.

Fairweather J (2008). Linking evidence and promising practices in science, technology, engineering, and mathematics (STEM) education: a status report. Commissioned paper presented at NRC workshop on Evidence on Selected Promising Practices in Undergraduate Science, Technology, Engineering, and Mathematics (STEM) Education, Washington, DC. www .nsf.gov/attachments/117803/public/Xc-Linking_Evidence-Fairweather .pdf (accessed 11 September 2015).

Feldon D, Timmerman BC, Stowe KA, Showman R (2010). Translating expertise into effective instruction: the impacts of cognitive task analysis (CTA) on lab report quality and student retention in the biological sciences. J Res Sci Teach 47, 1165-1185.

Fink LD (2013). Creating Significant Learning Experiences: An Integrated Approach to Designing College Courses, San Francisco, CA: JosseyBass.

Freeman S, Eddy SL, McDonough M, Smith MK, Okoroafor N, Jordt H, Wenderoth MP (2014). Active learning increases student performance in science, engineering, and mathematics. Proc Natl Acad Sci USA 111 8410-8415.

Freeman S, Haak D, Wenderoth MP (2011). Increased course structure improves performance in introductory biology. CBE Life Sci Educ 10, 175186.

Gess-Newsome J, Southerland SA, Johnston A, Woodbury S (2003). Educational reform, personal practical theories, and dissatisfaction: the anatomy of change in college science teaching. Am Educ Res $\mathrm{J} 40$, 731-767.

Giersch S, McMartin F (2014). Promising Models and Practices to Support Change in Entrepreneurship Education, Epicenter Technical Brief 2, Stanford, CA/Hadley, MA: National Center for Engineering Pathways to Innovation.

Gormally C, Evans M, Brinkman P (2014). Feedback about teaching in higher ed: neglected opportunities to promote change. CBE Life Sci Educ 13, 187-189.

Gross D, Pietri ES, Anderson G, Moyano-Camihort K, Graham MJ (2015). Increased preclass preparation underlies student outcome improvement in the flipped classroom. CBE Life Sci Educ 14, ar36.

Grossman R, Salas E (2011). The transfer of training: what really matters? Int J Train Devel 15, 103-120.

Gruppen LD, Froha AZ, Anderson RM, Lowe KD (2003). Faculty development for educational leadership and scholarship. Acad Med 78, 137-141.

Haak DC, HilleRisLambers J, Pitre E, Freeman S (2011). Increased structure and active learning reduce the achievement gap in introductory biology. Science 332, 1213-1216.

Henderson C, Dancy MH, Niewiadomska-Bugaj M (2012). Use of research-based instructional strategies in introductory physics: where do 
faculty leave the innovation-decision process? Phys Rev ST Phys Educ Res 8, 020104.

Hilborn RC (2012). The Role of Scientific Societies in STEM Faculty Workshops: A Report of the May 3, 2012 Meeting, Washington, DC: Council of Scientific Society Presidents, American Chemical Society. www.aapt.org/ Conferences/newfaculty/upload/STEM_REPORT-2.pdf (accessed 11 September 2015).

Jacobs GH, Nathans J (2009). The evolution of primate color vision. Sci Am $300,56-63$

Kezar A (2009). Synthesis of scholarship on change in higher education. Paper presented at Mobilizing STEM Education for a Sustainable Future, Atlanta, GA, January 4-6, 2009

King KP (2004). Both sides now: examining transformative learning and professional development of educators. Innov High Educ 29(2), 155-174.

Kober N (2015). Reaching Students: What Research Says About Effective Instruction in Undergraduate Science and Engineering, Washington, DC: National Academies Press.

Lenning OT, Hill DM, Saunders KP, Solan A, Stokes A (2013). Powerful Learning Communities: A Guide to Developing Student, Faculty, and Professional Learning Communities to Improve Student Success and Organizational Effectiveness, Sterling, VA: Stylus.

Linton DL, Pangle WM, Wyatt KH, Powell KN, Sherwood RE (2014). Identifying key features of effective active learning: the effects of writing and peer discussion. CBE Life Sci Educ 13, 469-477.

Lovett MC (2013). Make exams worth more than the grade: using exam wrappers to promote metacognition. In: Using Reflection and Metacognition to Improve Student Learning Across the Disciplines, Across the Academy, ed. M Kaplan, N Silver, D Lavaque-Manty, and D Meizlish, Sterling, VA: Stylus.

Lund TJ, Stains M (2015). The importance of context: an exploration of factors influencing the adoption of student-centered teaching among chemistry, biology, and physics faculty. Intl J STEM Educ 2(1), 1-21.

Mack MR, Towns MH (2016). Faculty beliefs about the purposes for teaching undergraduate physical chemistry courses. Chem Educ Res Pract 17(1), $80-99$.

Major CH, Palmer B (2006). Reshaping teaching and learning: the transformation of faculty pedagogical content knowledge. High Educ 51, 619-647.

Margolis E (ed.) (2001). The Hidden Curriculum in Higher Education, London: Routledge.

Mayer RE, Alexander PA (2011). Handbook of Research on Learning and Instruction, London: Routledge.

McDaniel EA (1987). Faculty collaboration for better teaching: adult learning principles applied to teaching improvement. To Improve the Academy 6 , 94-102.

McGehee W, Thayer PW (1961). Training in Business and Industry, Hoboken, $\mathrm{NJ}$ : Wiley.

Michael J (2007). Faculty perceptions about barriers to active learning. Coll Teach 55, 42-47.

Moog RS, Creegan FJ, Hanson DM, Spencer JN, Straumanis AR (2006). Process-oriented guided inquiry learning: POGIL and POGIL project. Metropol Univ J 17(4), 41-51.

Mulnix A (2013). Communicating a new model: learner-centered strategies in faculty development. J Cent Teach Learn 5, 23-47.

Mulnix AB (2003). Investigations of protein structure and function using scientific literature: an assignment for an undergraduate cell physiology course. Cell Biol Educ 2, 248-255.

Mulnix AB (2016). What my cadaver dog taught me about teaching and learning. J Excell Coll Teach 27, 1-18.

Mulnix AB, Penhale SJ (1997). Modeling the activities of scientists: a literature review and poster presentation assignment. Am Biol Teach 59, 482-487.

Mulnix AB, Vandegrift E, Chaudhury R (2016). How important is achieving undergraduate STEM equity to you? J Coll Sci Teach 45, 6-9.
National Research Council (NRC) (2000). How People Learn: Brain, Mind Experience, and School, expanded ed., Washington, DC: National Academies Press.

NRC (2012a). Discipline-based education research: understanding and improving learning in undergraduate science and engineering. In: Committee on the Status, Contributions, and Future Directions of Discipline-Based Education Research. Board of Science Education, Division of Behavioral and Social Sciences and Education, ed. SR Singer, NR Nielsen, and HA Schweingruber, Washington, DC: The National Academies Press.

NRC (2012b). Education for Life and Work: Developing Transferable Knowledge and Skills in the 21st Century, Washington, DC: National Academies Press.

Nelson CE (2010). Dysfunctional illusions of rigor: lessons from the scholarship of teaching and learning. To Improve the Academy 281, 77-92.

Offerdahlt EG, Montplaisir L (2013). Student-generated reading questions: diagnosing student thinking with diverse formative assessments. Biochem Mol Biol Educ 42, 29-38.

President's Council of Advisors on Science and Technology (2012). Engage to Excel: Producing One Million Additional College Graduates with Degrees in Science, Technology, Engineering, and Mathematics, Washington, DC: U.S. Government Office of Science and Technology.

Pusateri TP (2014). How SoTL can contribute to faculty development and institutional decisions. In: Using SoTL to Enhance Your Academic Position, ed. RA Smith and BM Schwartz, Washington, DC: Society for the Teaching of Psychology, 88-81. http://teachpsych.org/ebooks, (accessed 20 October 2016).

Richardson V (1990). Significant and worthwhile change in teaching practice. Educ Res 19(7), 10-18

Shulman LS (1986). Those who understand: knowledge growth in teaching Educ Res 15(2), 4-14

Slavich GM, Zimbardo PG (2012). Transformational teaching: theoretical underpinnings, basic principles, and core methods. Educ Psychol Rev 24, 569-608.

Smith J, Wilson SB, Banks J, Zhu L, Varma-Nelson P (2014). Replicating peerled team learning in cyberspace: research, opportunities and challenges. J Res Sci Teach 51, 714-740.

Sousa D (2010). Mind, Brain, and Education: Neuroscience Implications for the Classroom, Bloomington, IN: Solution Tree.

Stewart C (2014). Transforming professional development to professional learning. J Adult Educ 43, 28-33.

Stockwell BR, Stockwell MS, Cennamo M, Jiang E (2015). Blended learning improves science education. Cell 162, 933-936.

Sunal DW, Hodges J, Sunal CS, Whitaker KW, Freeman LM, Edwards L, Johnston RA, Odell M (2001). Teaching science in higher education: faculty professional development and barriers to change. School Sci Math $101,246-257$

Talanquer V (2014). DBER and STEM education reform: are we up to the challenge? J Res Sci Teach 51, 809-811.

Tobias S (1992). Revitalizing Undergraduate Science: Why Some Things Work and Most Don't, An Occasional Paper on Neglected Problems in Science Education, Tucson, AZ: Research Corporation.

Vescio V, Ross D, Adams A (2008). A review of research on the impact of professional learning communities on teaching practice and student learning. Teach Teach Educ 24, 80-91.

Weimer M (2013). Learner-Centered Teaching, San Francisco, CA: JosseyBass.

Wood WB (2009). Innovations in teaching undergraduate biology and why we need them. Annu Rev Cell Dev Biol 25, 93-112.

Zakrajsek TD (2013). Scholarly teaching: suggestions for a road more traveled. Int J Scholarsh Teach Learn 7(10). http://digitalcommons .georgiasouthern.edu/ij-sotl/vol7/iss1/2 (accessed 20 October 2016).

Zhang X, Mclnerney J, Frechting J (2010). Learning after you know it all: when STEM faculty teach teachers, who learns? Change 42, 24-28. 